\title{
Who do type 2 diabetics inform about their own illness
}

\author{
AGATA MATEJ-BUTRYM ${ }^{1, A-G}$, MAREK BUTRYM ${ }^{2, c-F}$, \\ EWA RUDNICKA-DROŻAK ${ }^{1, D, E}$, JOLANTA SZELIGA-KRÓL ${ }^{1, D, E}$
}

${ }^{1}$ Chair and Department of Family Medicine, Medical University of Lublin, Poland

${ }^{2}$ Department of Sociology, University of Warmia and Mazury in Olsztyn, Poland

A - Study Design, B - Data Collection, C - Statistical Analysis, D - Data Interpretation, E - Manuscript Preparation, F - Literature Search, G - Funds Collection

Summary Background. Type 2 diabetes is a chronic disease that can influence the relationship between patients and their social environment. Some diabetics are afraid of discrimination because of their illness.

Objectives. Understanding who of their social circle those afflicted with type 2 diabetes inform of the course of their disease.

Material and methods. 136 patients with type 2 diabetes, including 71 women and 65 men (age - median: 62.5, min-max: 40-84) were subjected to a survey study which included, firstly, questions on who they inform about their affliction, secondly, the degree to which they admit to the affliction as compared with selected carbohydrate metabolism parameters of their illness $\left(\mathrm{HbA}_{1 \mathrm{c}^{\prime}}\right.$ fasting glucose).

Results. Regarding their affliction, patients with type 2 diabetes most often inform their family members of their state of being, especially those who live with them $(99.1 \% ; 111)$, as well as those who do not live with them $(86 \% ; 117)$, then other people with diabetes $(80.1 \% ; 109)$, friends $(72.8 \% ; 99)$ and neighbours $(63.2 \% ; 86)$. In contrast, every second employed respondent did not inform their employer. The reason for admission to being type 2 diabetic was primarily motivated by a desire to prove that they can live a normal life while diabetic $(60.3 \%$; 86$)$. There is a negative correlation between the level of $\mathrm{HbA}_{1 \mathrm{c}}$ and a willingness to reveal that the afflicted can live a normal life despite their diabetes $(p<0,05)$.

Conclusions. Our research shows that type 2 diabetics do not always inform certain people within their social environment about their illness. This may have negative consequences. The reasons for this behavior require further research.

Key words: diabetes mellitus type 2 , family, social distance, social environment.

Matej-Butrym A, Butrym M, Rudnicka-Drożak E, Szeliga-Król J. Who do type 2 diabetics inform about their own illness. Fam Med Prim Care Rev 2018; 20(3): 236-240, doi: https://doi.org/10.5114/fmpcr.2018.78258.

\section{Background}

In recent decades, the prevalence of diabetes has risen sharply around the world. According to estimates of the International Diabetes Federation, there are currently 451 million people with diabetes aged 18-99 in the world, and it is predicted that by 2045, this number will increase to 629 million [1]. Is this increasing number of people with diabetes getting more and more understanding and social support? Can any person suffering from diabetes always and everywhere admit to being diabetic?

In the literature, we encounter the problem of stigmatization and discrimination of people with diabetes. People who do not suffer from diabetes assume that diabetes is not a stigma [2]. In contrast, people with diabetes report that stigmatization is a serious problem for them - one which they experience in different areas of life, especially in the workplace or in relationships [2].

In the U.S., a study was carried out to measure the stigma of diabetes and the associated psychosocial effects within a large population of patients, using an online survey sent to 12,000 people with diabetes [3]. The results reveal that the majority of respondents with type 1 diabetes (76\%) or type 2 diabetes (52\%) reported that diabetes is associated with stigma [3].

The Second Diabetes Attitudes, Wishes and Needs (DAWN2) study, which covered over 8.500 adult diabetics from 17 countries, showed that $17.6 \%$ of all patients thought their affliction generated discrimination, intolerance and a lack of support from the communities in which they lived [4]. In Poland, the percentage of patients declaring similar experiences was higher and amounted to as much as $24 \%$ [4]. It is disturbing that even the very fact of becoming diabetic may cause shame in some people [5]. Such feelings of shame can prevent the afflicted from informing people within their social environment about the illness. This can have a negative impact on the course of diabetes therapy.

In the literature devoted to the problem of informing about the disease, we find, first of all, issues concerning the manner in which medical personnel inform the afflicted about the course of their disease. The intent of the provided information is to compel the patient to adopt their doctor's recommendations, and, consequently, to ensure effectiveness of the therapy. It is also emphasized that information of this nature, regardless of what disease it concerns, creates a specific doctor-patient relationship and builds the patient's trust [6] and their willingness to care for their own health.

The problem of providing crucial information to the patient's family, is considerably less often taken [7]. When done correctly, doing so fulfils similar goals, because the patient expects understanding, support and acceptance from their family members. Indeed, the importance of the family has an additional dimension as the family has significance with regard to medical care and health protection, especially in chronic diseases, as it partners the health care system in performing traditional health-related tasks [8].

In everyday diabetological practice, however, we encounter situations wherein patients signal that they do not always admit to having diabetes. It is likely that in such scenarios, the 
afflicted fear potential discrimination or stigmatization should they admit to being diabetic. Analyses of the information that the ill person communicates with their social environment are only occasionally performed/carried out. The only material available in the literature are individual studies on the concealment or disclosure of information about the disease by patients with diabetes, especially in the workplace [9-11]. Thus, there is a need to understand the social implications of being diabetic.

\section{Objectives}

The aim of the study is to understand why those afflicted with type 2 diabetes inform only certain individuals within their social circles, of the course of their disease. An attempt was also made to estimate the relationship between the fact of limiting admission of being diabetic and the values of the selected parameters of metabolic diabetes control.

\section{Material and methods}

\section{Setting and participants}

The study covered 136 patients with type 2 diabetes, including 71 women and 65 men (age - median 62.5, min-max 40-84) who reported to the Diabetological Outpatient Clinic of the Chair and Department of Family Medicine, Medical University of Lublin, for a medical appointment within a 6 month period, i.e. from September 2007 to February 2008.

The study used a previously developed original questionnaire assessing the socio-economic and family situation of patients with type 2 diabetes [12]. The respondents were asked to indicate people from their social environment (family members, friends, neighbours and others) who they inform about their illness. The respondents also gave reasons for telling others about their disease. The categories of causes included the expectation of greater emotional support, maintenance of dignity, as well as the health, social and professional safety of the patient. The metabolic control of diabetes was assessed based on the level of A1c glycated haemoglobin $\left(\mathrm{HbA}_{1 \mathrm{c}}\right.$ ) and fasting plasma glucose in the venous blood. Satisfactory values of fasting glucose was assumed to be $\leq 110 \mathrm{mg} / \mathrm{dl}$ and for $\mathrm{HbA}_{1 \mathrm{c}} \leq 7 \%$.

The study design received a positive opinion from the Bioethics Committee (KE-0254/116/2007).

\section{Statistical methods}

The statistical analysis was performed using the IBM SPSS program version 25. The Pearson $\chi^{2}$ test was used in order to determine the statistical significance of the correlation between the variables. Values below 0.05 were assumed to be significant. The Kolmogorov-Smirnov test with the Lilliefors correction was used to ascertain normal distribution, herein, the confidence interval was set at the average of $95 \%$. Age did not have normal distribution, but variables such as duration of diabetes, fasting glucose and $\mathrm{HbA}_{1 \mathrm{c}}$ had. Descriptives of the group are presented in Table 1.

\begin{tabular}{|l|l|l|l|l|l|}
\hline \multicolumn{7}{|l|}{ Table 1. Descriptives of the group } \\
\hline Variable & Median & Min-max & Mean & SD & $\begin{array}{l}\text { K-S Test } \\
\text { Sig. }\end{array}$ \\
\hline Age & 62.50 & $40-84$ & 62.65 & 8.865 & 0.199 \\
\hline $\begin{array}{l}\text { Duration of } \\
\text { diabetes }\end{array}$ & 7.00 & $1-29$ & 8.72 & 6.898 & $<0.001$ \\
\hline $\begin{array}{l}\text { Fasting } \\
\text { glucose }\end{array}$ & 116.50 & $51-249$ & 122.22 & 31.471 & $<0.001$ \\
\hline $\mathrm{HbA}_{1 \mathrm{c}}$ & 6.50 & $3.6-9.8$ & 6.60 & 6.599 & $<0.001$ \\
\hline
\end{tabular}

\section{Results}

\section{Participants and descriptive data}

Persons aged $<65$ years accounted for $55.9 \%$ (76) of the respondents, and those aged $\geq 65$ years $-44.1 \%(60)$. The vast majority of the respondents lived in the city $(75.7 \% ; 103)$ and the remaining $24.3 \%$ (33) in the countryside. The percentage of the respondents living with at least one person in a household was $82.4 \%$ (112), and those living alone $-17.6 \%$ (24). Over $2 / 3$ of the respondents $(67.4 \%$; 91$)$ were married and the remaining $32.6 \%$ (44) were unmarried. The group characteristics are presented in Table 2.

\begin{tabular}{|l|l|l|l|}
\hline \multicolumn{4}{|l|}{ Table 2. Characteristics of the group $n=136$} \\
\hline Parameter & $<65$ years & $\%$ & $n$ \\
\hline \multirow{2}{*}{ Age } & $\geq 65$ years & 55.9 & 76 \\
\hline \multirow{2}{*}{ Sex } & men & 44.1 & 60 \\
\cline { 2 - 4 } & women & 47.8 & 65 \\
\hline Marital status & married & 52.2 & 71 \\
\cline { 2 - 4 } & unmarried & 67.6 & 92 \\
\hline \multirow{3}{*}{ Place of residence } & city & 32.4 & 44 \\
\cline { 2 - 4 } & country & 75.7 & 103 \\
\hline \multirow{3}{*}{ Living in a household } & $\begin{array}{l}\text { with at least one } \\
\text { person }\end{array}$ & 24.3 & 33 \\
\cline { 2 - 4 } & alone & 82.4 & 112 \\
\hline
\end{tabular}

People with vocational and secondary education dominated among the respondents (66.9\%; 91), 18.4\% (25) had primary and $14 \%(19)$ - higher education. Most of the respondents were professionally inactive $(72.1 \%$; 98$)$. The people from the professionally active group were divided into employed $(84.2 \% ; 32)$ and self-employed $(15.8 \% ; 6)$. The mean duration of diabetes in the study group was 8.72 years $(S D=6.898)$.

The mean fasting blood glucose level in the study group was $122.22 \mathrm{mg} / \mathrm{dl}$ (SD = 31.471). In 61\% (83) of the subjects, the fasting blood glucose level exceeded $110 \mathrm{mg} / \mathrm{dl}$. The mean $\mathrm{HbA}_{1 \mathrm{c}}$ in the study group was $6.6 \%(\mathrm{SD}=6.599)$. Satisfactory $\mathrm{HbA}_{1 c}$ values $(\leq 7 \%)$ were reported in $78.7 \%(107)$ of the subjects.

\section{Main results}

It appears that there are four groups of people who are most often informed by patients with type 2 diabetes with regard to their illness: 1) family members - both those who live with the patient $(99.1 \% ; 111)$ and those who do not live with the patient $(86.0 \% ; 117), 2)$ other people with diabetes $(80.1 \% ; 109)$, 3 ) friends $(72.8 \% ; 99)$ and 4$)$ neighbours $(63.2 \% ; 86)$ (Figure 1). Persons at workplace are less frequently informed about the disease. Every second employed respondent $(50 \% ; 16)$ provided his/ /her employer with the information about the disease; a slightly larger percentage of patients $(57.3 \% ; 18)$ inform their workmates.

With regard to their disease, all persons living alone informed family members not living with them, whereas patients who lived with at least one person rarely inform family members not living with them about their illness (100\% (24) and 83\% (93), respectively, $p=0.03$ ). People who are professionally inactive more often informed their friends about the disease than did those professionally active $(77.6 \%(76)$ and $60.5 \%(23)$, respectively, $p=0.045$ ).

Neighbours are an important category of people informed by patients about their illness. The variables which differentiate the frequency of informing neighbours include: 1) sex - more often women than men $(71.8 \%(51)$ and $53.8 \%(35)$, respectively, $p=0.03)$, 2) age - more often older people aged $\geq 65$ years than those younger (75\% (45) and $53.9 \%(41)$, respectively, $p=0.011$ ), 
Neighbours $63.2 \%$

Friends $72.8 \%$

Other people with diabetes $80.1 \%$

Family members not living with the patient $86.0 \%$

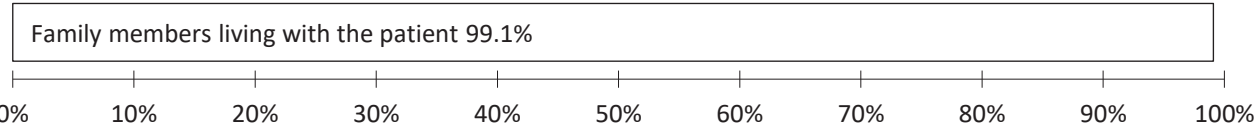

Figure 1. Persons most frequently informed by patients about their disease

$\square$ want to prove that "a person can live a normal life with diabetes"

$\%$

$\square$ want to obtain help in the case of hypoglycaemia

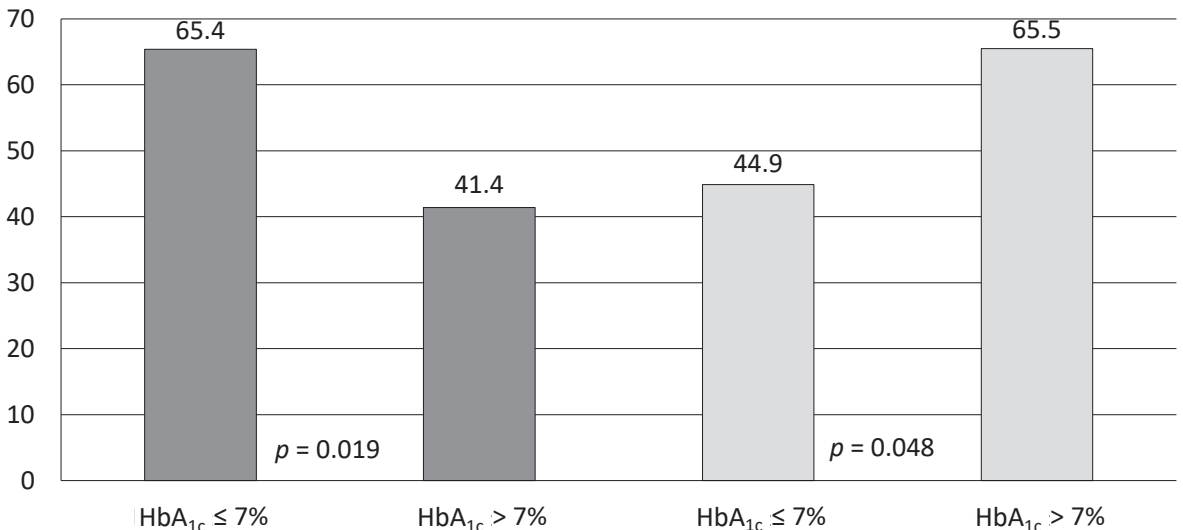

Figure 2. Percentage of subjects with normal and abnormal $\mathrm{HbA}_{1 \mathrm{c}}$ level depending on the motivation to inform about their own illness

3) marital status - more often unmarried than married people $(77.8 \%(35)$ and $56 \%(51)$, respectively, $p=0.013)$ and 4$)$ professional activity - the professionally inactive more often informed neighbours about their disease than did those who are professionally active $(70.4 \%(69)$ and $44.7 \%(17)$, respectively, $p=0.005)$.

Informing about the disease was primarily motivated by a desire to prove that "a person with diabetes can live a normal life" (60.3\%; 82), but also by the rule of reciprocity, "because others also told me about their illness" (54.4\%; 74$)$ as well as for safety reasons "so that others could help me in case of hypoglycaemia" (49.3\%; 67). The concern about one's own safety and the course of therapy was also reflected in other reasons given by the respondents: "so that they would understand me" $(47.8 \% ; 65)$, "so that they would not hinder my compliance with medical recommendations" (47.8\%; 65), "so that they would gain knowledge about diabetes" $(46.3 \%$; 63$)$, "so that they could help me comply with medical recommendations" (31.6\%; 43). Only a small percentage of respondents did so so as to obtain more kindness/friendliness (14.7\%; 20) and care (9\%; 12$)$.

People with well-controlled diabetes $\left(\mathrm{HbA}_{1 \mathrm{c}} \leq 7 \%\right)$ more often than those with poorly-controlled diabetes $\left(\mathrm{HbA}_{1 \mathrm{c}}>7 \%\right)$ are willing to prove that "a person can live a normal life with diabetes" (65.4\% (70) and $41.4 \%(12)$, respectively, $p=0.019)$. On the other hand, patients with the level of $\mathrm{HbA}_{1 \mathrm{c}}>7 \%$ more often than patients with $\mathrm{HbA}_{1 \mathrm{c}} \leq 7 \%$ inform about their disease for safety reasons, in order to obtain help in the case of hypoglycaemia ( $65.5 \%$ (19) and $44.9 \%$ (48), respectively, $p=0.048$ ) (Figure 2).

Patients living in the countryside more often than people from the city inform about their illness based on the rule of reciprocity, because others also told them about the disease $(69.7 \%$ (23) and $49.5 \%(51)$, respectively, $p=0.043)$. Men more often than women expect understanding of their situation (56.9\% (37) and $39.4 \%(28)$, respectively, $p=0.041$ ). Similarly, older patients ( $\geq 65$ years) more frequently than younger mentioned the willingness to be understood by people they inform about the disease $(60 \%$ (36) and $38.2 \%(29)$, respectively, $p=0.011)$. As for the needs related to diabetes therapy, the situation is similar. The older the person, the more willingly he/she speaks about his/her illness so that others would not hinder their compliance with medical recommendations (60\% (36) and 38.2\% (29), respectively, $p=0.011$ ). Also more often, older patients who inform others about their disease expect help in compliance with medical recommendations $(46.7 \%(28)$ and $19.7 \%(15)$, respectively, $p=0.001$ ). People who are professionally inactive more frequently than those professionally active inform others about their health problem in the hope of receiving help in complying with medical recommendations (37.8\% (37) and $15.8 \%$ (6), respectively, $p=0.013$ ). People living in a household with at least one person, as opposed to those living alone, expected to be relived of some duties due to their affliction $(15.2 \%$ (17) and $0 \%$ (0), respectively, $p=0.041$ ).

No statistically significant relationship was demonstrated between the fact of informing about the disease and education, duration of diabetes and fasting glucose level.

\section{Discussion}

\section{Key results and interpretation}

The results of the study confirm literature data that the family is the most important source of support for diabetic patients 
[13-15]. Ławska et al. also showed that the majority of diabetics expect help from their family [16]. The near family is considered the group of the greatest trust with regard to freely informing about the affliction without the expectation of negative reactions. Indeed, Stopford et al. concluded that the family support is most often associated with the reduction of $\mathrm{HbA}_{1 \mathrm{c}}$ level [14]. The study conducted by Mohebi et al. also revealed that patients with higher $\mathrm{HbA}_{1 \mathrm{c}}$ values felt less social support [17].

Another large group ( $80 \%$ ) informed by patients about their disease are other people with diabetes. The analysis of reasons for informing such about diabetes has shown that more than half of patients shared the information about their illness with other patients based on the rule of reciprocity. The exchange of experience and mutual assistance between patients with diabetes may, on the one hand, improve patients' self-esteem, and on the other hand, expand their knowledge about treatment, self-care and coping strategies. It seems that this should be an indication for family doctors, diabetologists and other members of the therapeutic team that it is worth encouraging people suffering from diabetes to actively participate in various types of support groups and associations for diabetics.

It was also demonstrated that friends and neighbours are important social groups. Almost $2 / 3$ of all patients with diabetes trust their neighbours and tell them about their illness. These are more often women, older people aged $\geq 65$ years old, unmarried persons and those professionally inactive. It seems that with time, neighbourhood ties tighten and neighbours can be an important source of support for patients in the treatment of type 2 diabetes. On the other hand, unmarried persons more often than married inform neighbours about their illness hoping for support. Shaw et al. demonstrated that neighbours and neighbourhood resources seem to have a great impact "on adherence to diabetes self-care behaviours" [13].

The study found that the main reason why patients with type 2 diabetes informed others about their illness was a desire to prove that "you can live a normal life with diabetes". This belief is more common among patients with well-controlled diabetes $\left(\mathrm{HbA}_{1 \mathrm{c}} \leq 7 \%\right)$ who set a good example, and, in this way, can convince other patients that diabetes can be overcome and that they enjoy all areas of life. It was also demonstrated that, on average, every second patient with diabetes informs others about their illness, expecting help in case of hypoglycaemia, understanding of the disease and non-hindrance in their compliance with medical recommendations or is motivated by a willingness to share experience and knowledge about diabetes.

Interestingly, patients with poor glycemic control $\left(\mathrm{HbA}_{1 \mathrm{c}}\right.$ $>7 \%$ ) far more often than patients with good glycemic control $\left(\mathrm{HbA}_{1 \mathrm{c}} \leq 7 \%\right)$ inform their social environment about their illness, expecting help in case of hypoglycaemia. This may be an important hint for doctors dealing with the therapy of diabetic patients that high $\mathrm{HbA}_{1 c}$ levels in these patients may be due to fear of hypoglycaemia and to a deliberate maintenance of glycemia at a higher level. This is especially true for patients who have experienced a serious episode of hypoglycaemia and for fear of another episode, consciously reduce insulin doses or consume an additional meal [18]. On the other hand, unsatisfactory $\mathrm{HbA}_{1 \mathrm{c}}$ values may occur in patients with unstable diabetes, or with frequent episodes of hypoglycaemia and hyperglycaemia. Lipska et al. showed that severe hypoglycaemia was common in patients with type 2 diabetes at all levels of glycemic control, and the risk was usually higher in patients with almost normal glycemia or very poor glycemic control [19].

Physicians and other health care providers should encourage diabetic patients to wear identifiers with information that they suffer from diabetes, so that even a person accidentally met can give them first aid if needed. This is particularly important when an episode of hypoglycaemia occurs, the symptoms of which may mimic the state of alcohol intoxication [18]. Moreover, people who have different social relations with a patient suffering from diabetes, unaware of his illness and problems related to hypoglycaemia and diabetes therapy, may downplay the symptoms of hypoglycaemia, as well as fail to support the patient in compliance with medical recommendations, especially in the use of diet.

Our study showed that every second employed respondent does not inform his employer about the diagnosis of diabetes. Similar results were obtained by Hakkarainen et al. in a study conducted on Finnish workers with type 1 diabetes - only half of subjects disclosed their diabetes at work [10]. Olesen et al. in a study conducted among Danish workers with type 2 diabetes, stated that $23 \%$ did not disclose their illness to their employer [11]. Munir et al. examined in the United Kingdom workers treated for chronic disease (arthritis, musculoskeletal pain, diabetes, asthma, migraine, heart disease, irritable bowel syndrome, depression) and stated that "except for diabetes, chronic illness itself was not a significant predictor or barrier to self-disclosure" [20]. Failure to inform the employer or workmates about their illness by diabetic patients can have negative consequences, especially in the event of loss of consciousness due to hypoglycaemia, which may pose a serious threat to the health and even life of not only the patient, but also people in its environment [21]. This is especially true for workplaces where the fainting of a sick employee with diabetes (e.g. drivers) may endanger other people in a different way. Ruston et al. also showed that diabetic patients were reluctant to disclose their illness at work and reported the need for support if they were stigmatized or treated inappropriately, e.g. if symptoms of hypoglycaemia occur. He stated that diabetic employees strive to maintain glycemic values at a higher than recommended level to prevent hypoglycaemia or exposing oneself to the development of chronic diabetes complications [22].

\section{Limitations of the study}

The results of our study concern a group of patients with type 2 diabetes, characteristic of the older age category, in a large percentage of the professionally passive. This does not give a full orientation in the problems of informing about the disease by a larger group of patients with diabetes with more diversified demographic characteristics and professional and family situations. Future research should be extended to patients with type 1 diabetes, and in younger age categories, including a larger group of professionally active patients.

\section{Conclusions}

1. Patients with type 2 diabetes most often inform their family and people with diabetes of their situation, and the least frequently the employer.

2. The main reason for informing others about the illness is a desire to prove that "you can live a normal life with diabetes".

3. There is a negative correlation between the $\mathrm{HbA}_{1 c}$ level and a willingness to prove that "you can live a normal life with diabetes".

4. There is a positive correlation between $\mathrm{HbA}_{1 \mathrm{c}}$ and the expectation of receiving help in case of hypoglycaemia.

5. Family physicians should encourage patients with diabetes to inform others about their illness, especially in workplaces, both for their own safety and for the safety of people in their environment.

6. Failure to inform the social environment about the diagnosis of diabetes can have negative consequences for the health and life of both the patient and people from the social environment. The reasons for this behavior require further research.

Source of funding: This paper was developed using the university's funds and authors' own resources.

Conflict of interest: The authors declare no conflict of interests. 


\section{References}

1. Cho NH, Shaw JE, Karuranga S, et al. IDF Diabetes Atlas: global estimates of diabetes prevalence for 2017 and projections for 2045. Diabetes Res Clin Pract 2018; 138: 271-281.

2. Schabert J, Browne JL, Mosely K, et al. Social stigma in diabetes: a framework to understand a growing problem for an increasing epidemic. Patient 2013; 6: 1-10.

3. Liu NF, Brown AS, Younge MF, et al. Stigma in people with type 1 or type 2 diabetes. Clin Diabetes 2017; 35: 27-34.

4. Foryciarz K, Obrębski M, Kokoszka A. Results of the second Diabetes Attitudes, Wishes and Needs (DAWN2) study: overview of the most important results from the Polish perspective. Clin Diabetol 2016; 5(6): 185-194.

5. Hamerlińska-Latecka A. Wstydzę się swojej choroby, czyli o cukrzycy i poczuciu wstydu. Diabetol na co dzień 2011; 3(24): 32-34 (in Polish).

6. Ostrowska A, ed. Jak rozmawiać z pacjentem? Anatomia komunikacji w praktyce lekarskiej. Warszawa: Polska Liga Walki z Rakiem; 2017 (in Polish).

7. Włoszczak-Szubzda A, Jarosz MJ. Rola i znaczenie komunikacji w relacji lekarz-pacjent-rodzina. Med Og Nauk Zdr 2012; 18(3): 206-211 (in Polish).

8. Jarosz MJ, Kawczyńska-Butrym Z, Włoszczak-Szubzda A. Modele komunikacyjne relacji lekarz-pacjent-rodzina. MONZ 2012; 18(3): 212-218 (in Polish).

9. Hakkarainen P, Munir F, Moilanen L, et al. Concealment of type 1 diabetes at work in Finland: a mixed-method study. BMJ Open 2018; 8(1): e019764, doi:10.1136/bmjopen-2017-019764.

10. Hakkarainen P, Moilanen L, Hänninen V, et al. Disclosure of Type 1 diabetes at work among finnish workers. Diabet Med 2017; 34(1): 115-119.

11. Olesen K, Cleal B, Skinner T, et al. Characteristics associated with non-disclosure of Type 2 diabetes at work. Diabet Med 2017; 34(8): $1116-1119$.

12. Matej-Butrym A. Wpływ czynników socjoekonomicznych i rodzinnych na przebieg leczenia pacjentów z cukrzycą typu 2. (Rozprawa doktorska). Lublin: Uniwersytet Medyczny; 2010 (in Polish).

13. Shaw BA, Gallant MP, Riley-Jacome M, et al. Assessing sources of support for diabetes self-care in urban and rural underserved communities. J Community Health 2006; 31: 393-412.

14. Stopford R, Winkley K, Ismail K. Social support and glycemic control in type 2 diabetes: a systematic review of observational studies. Patient Educ Couns 2013; 93: 549-558.

15. Matej-Butrym A, Schabowski J. Family support in compliance with recommendations for diet and metabolic control in patients with type 2 diabetes - preliminary report. Fam Med Prim Care Rev 2008; 10(3): 519-521.

16. Ławska W, Lubińska-Żądło B, Łyżnika M. Edukacja zdrowotna pacjentów z cukrzycą - ocena skuteczności. Zdr Pub/ 2004; 114(4): 537-540 (in Polish).

17. Mohebi S, Parham M, Sharifirad G, et al. Relationship between perceived social support and self-care behavior in type 2 diabetics: a cross-sectional study. J Educ Health Promot 2018; 3(7): 48, doi: 10.4103/jehp.jehp_73_17.

18. Łopatyński J, Chmiel-Perzyńska I. Hipoglikemia (niedocukrzenie) - co lekarz rodzinny powinien wiedzieć. Pol Med Rodz 2003; 5(3): 507-511 (in Polish).

19. Lipska KJ, Warton EM, Huang ES, et al. $\mathrm{HbA}_{1 \mathrm{c}}$ and risk of severe hypoglycemia in type 2 diabetes: the Diabetes and Aging Study. Diabetes Care 2013; 36(11): 3535-3542.

20. Munir F, Leka S, Griffiths A. Dealing with self-management of chronic illness at work: predictors for self-disclosure. Soc Sci Med 2005; 60(6): 1397-1407.

21. Walasiuk-Skorupa J, Wiszniewska M, Krawczyk-Szulc $P$, et al. Opieka profilaktyczna nad pracownikiem niepełnosprawnym - problem współczesnej medycyny pracy? Med Pr 2011; 62(2): 175-186 (in Polish).

22. Ruston A, Smith A, Fernardo B. Diabetes in the workplace-diabetic's perceptions and experiences of managing their disease at work: a qualitative study. BMC Public Health 2013; 13: 386, doi: https://doi.org/10.1186/1471-2458-13-386.

Tables: 2

Figures: 2

References: 22

Received: 15.05.2018

Reviewed: 29.05.2018

Accepted: 17.08 .2018

Address for correspondence:

Agata Matej-Butrym, MD, PhD

Katedra i Zakład Medycyny Rodzinnej UM

ul. Langiewicza $6 \mathrm{~A}$

20-032 Lublin

Tel.: +48 81 524-78-56

E-mail: amatej@wp.pl 